\title{
Chromosomal Distribution of Genes Conferring Tolerance to Abiotic Stresses Versus That of Genes Controlling Resistance to Biotic Stresses in Plants
}

\author{
Richard R.-C. Wang \\ USDA-ARS Forage and Range Research Lab, Utah State University, Logan, UT 84322-6300, USA; \\ richard.wang@usda.gov
}

Received: 29 February 2020; Accepted: 4 March 2020; Published: 6 March 2020

\section{Introduction}

Tolerance to abiotic stresses caused by environmental conditions can prevent yield loss in crops for sustaining agricultural productivity [1]. Resistance to biotic stresses caused by diseases and insects can prevent or reduce yield loss in crops [2]. For each crop or plant species, there are many abiotic threats, such as changes in temperature, soil salinity/alkalinity, water shortage, and soil contaminants, as well as biotic challenges from pathogens (bacteria, viruses, and fungi), insects, and nematodes. Plants need to possess genes conferring tolerance to these abiotic stresses to adapt to the changing environment, due to global climate changes, in which they are growing. Due to the coevolution of plants and stress-causing organisms [3], plants need to possess multiple resistance genes to deal with the rise of new virulence in stress-causing organisms. Plant breeders are constantly looking for new resistance genes to combat evolving organisms that pose a threat to susceptible crops. As a result, plant geneticists have identified many resistance genes in various crops, and molecular geneticists have developed molecular markers for most of those genes. Similarly, researchers are investigating plant mechanisms and underlying genetic systems involved in plant tolerance to abiotic stresses, hoping to breed crops resilient to adverse environmental conditions.

With the advent of whole-genome sequencing in many important crops, it is time to map the detailed chromosomal locations of known genes that are involved in tolerance to various abiotic stresses as well as in the resistance to biotic stresses in important plant species. In the Special Issue, "Mapping Abiotic Stress-Tolerance Genes in Plants" of International Journal of Molecular Sciences, 21 papers, including two reviews and 19 research articles, were published [4-24]. Eleven research articles [3,25-34] were published in the Special Issue "Mapping Plant Genes that Confer Resistance to Biotic Stress."

In this editorial, I firstly express my appreciation to all authors for their contribution to the two Special Issues. Secondly, I will compare the chromosomal distribution patterns of genes for the two types of stresses that plants faced (Tables 1 and 2). The evidence obtained supports my long-held hypothesis that genes conferring resistance to biotic stresses are more likely to be located in the distal portion of chromosomes than the proximal portion in order to adapt to the host-pest coevolution. On the other hand, abiotic-stress tolerance genes should have a lower ratio of distal to proximal distribution than that for biotic stresses to maintain the stability of genes regulating plant growth and development. Knowing the relationship between gene functions and their chromosomal distribution patterns, plant breeders can select the most appropriate and efficient method to improve crops for withstanding stresses and ensuring productivity and food security. 
Table 1. Chromosomal distribution of genes controlling tolerance to abiotic stresses

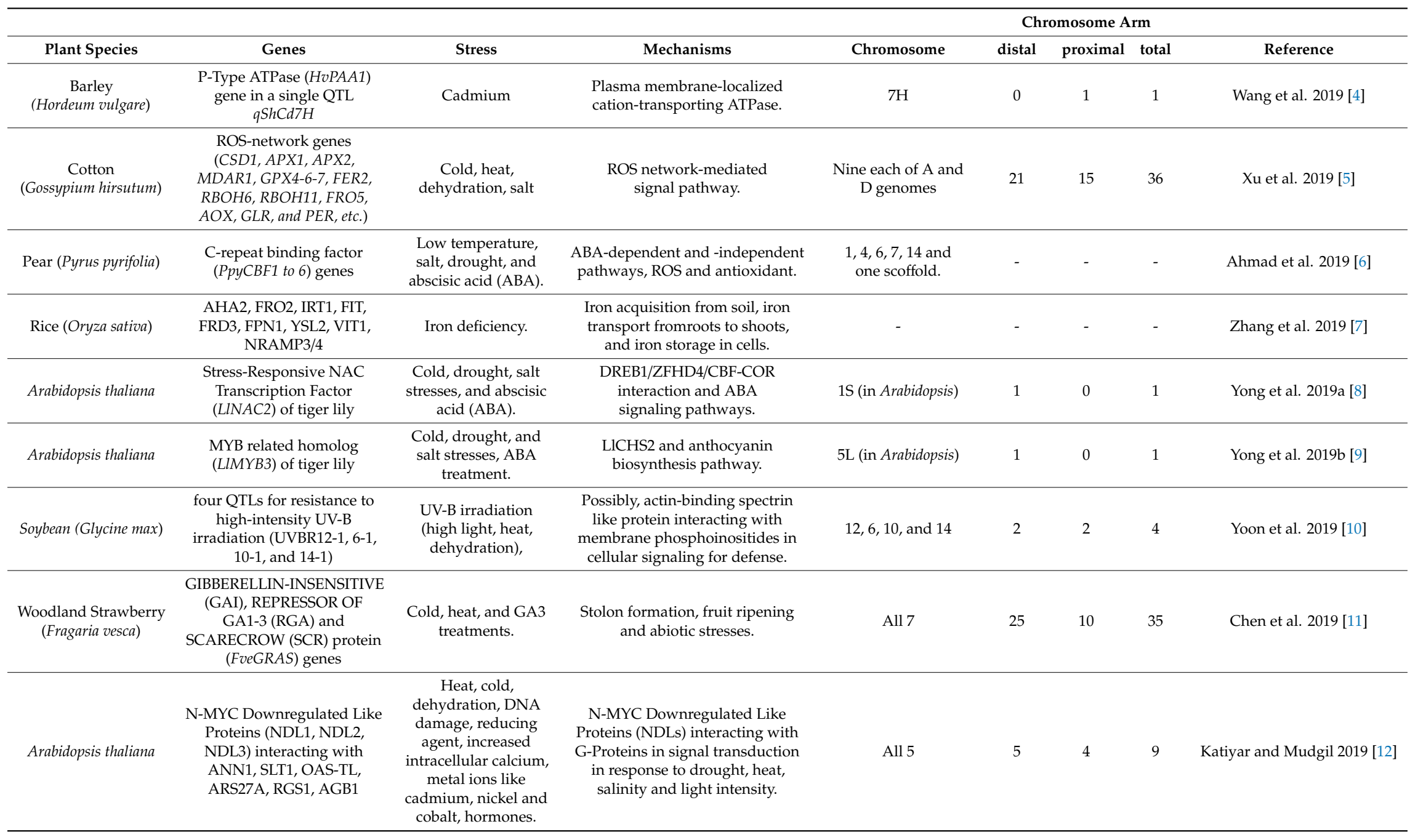


Table 1. Cont.

\begin{tabular}{|c|c|c|c|c|c|c|c|c|}
\hline \multirow[b]{2}{*}{ Plant Species } & \multirow[b]{2}{*}{ Genes } & \multirow[b]{2}{*}{ Stress } & \multirow[b]{2}{*}{ Mechanisms } & \multicolumn{5}{|c|}{ Chromosome Arm } \\
\hline & & & & Chromosome & distal & proximal & total & Reference \\
\hline Soybean (Glycine max) & $\begin{array}{c}\text { calmodulin binding } \\
\text { transcription activator gene } \\
(G m C A M T A)\end{array}$ & Drought. & $\begin{array}{l}\text { Calmodulin binding } \\
\text { Ca-CaM-CAMTA-mediated stress } \\
\text { regulatory mechanisms. }\end{array}$ & $\begin{array}{c}8 \text { out of } 20(5,7,8,9,11, \\
15,17,18)\end{array}$ & 10 & 5 & 15 & Noman et al. 2019 [13] \\
\hline $\begin{array}{c}\text { Cotton } \\
\text { (Gossypium hirsutum) }\end{array}$ & $\begin{array}{l}\text { nodule inception-like protein } \\
\text { (GhNLP) genes }\end{array}$ & Nitrogen deficiency & $\begin{array}{c}\text { Promoters of NLP genes interact } \\
\text { with stress-associated transcription } \\
\text { factors and be targeted by many } \\
\text { miRNAs. }\end{array}$ & All 26 & 91 & 14 & 105 & Magwanga et al. 2019 [14] \\
\hline $\begin{array}{c}\text { Cucumber } \\
\text { (Cucumis sativus L.) }\end{array}$ & $\begin{array}{c}\text { GAGA-binding BASIC } \\
\text { PENTACYSTEINE (BPC) } \\
\text { transcription factor genes } \\
\text { (CsBPCs) } \\
\end{array}$ & $\begin{array}{l}\text { Salt, drought, cold, } \\
\text { heat, ABA, SA, JA, } \\
\text { ETH, 2,4-D, GA. }\end{array}$ & $\begin{array}{c}\text { Germination, growth and } \\
\text { development, as well as responses } \\
\text { to abiotic stresses and plant } \\
\text { hormones. }\end{array}$ & 3 of $7(2,5,7)$ & 3 & 1 & 4 & Li et al. 2019 [15] \\
\hline $\begin{array}{c}\text { Carnation } \\
\text { (Dianthus caryophyllus) }\end{array}$ & $\begin{array}{l}\text { Heat shock transcription } \\
\text { factors (Hsfs) }\end{array}$ & $\begin{array}{l}\text { Heat, drought, cold, } \\
\text { salt, ABA, SA. }\end{array}$ & $\begin{array}{l}\text { Promoters included various } \\
\text { cis-acting elements that were } \\
\text { related to stress, hormones, as well } \\
\text { as development processes, } \\
\text { controlling reactive oxygen species } \\
\text { homeostasis, and ABA-mediated } \\
\text { stress signaling. }\end{array}$ & 17 scaffolds & 10 & 7 & 17 & Li et al. 2019 [16] \\
\hline $\begin{array}{c}\text { Cotton } \\
\text { (Gossypium hirsutum) }\end{array}$ & $\begin{array}{l}\text { Histone Acetyltransferase } \\
\text { (HAT) Gene family }\end{array}$ & $\begin{array}{l}\text { Salt, drought, cold, } \\
\text { heavy metal, DNA } \\
\text { damage, ABA, NAA. }\end{array}$ & $\begin{array}{l}\text { Affect cotton growth, fiber } \\
\text { development, and stress } \\
\text { adaptation by regulation of } \\
\text { chromatin structure, activate the } \\
\text { gene transcription implicated in } \\
\text { various cellular processes. }\end{array}$ & $\begin{array}{c}8 \text { of } 26(A-5,6,8,11 \text { and } \\
D-5,6,10,11)\end{array}$ & 16 & 2 & 18 & Imran et al. 2019 [17] \\
\hline $\begin{array}{c}\text { Chinese kale } \\
\text { (Brassica oleracea) }\end{array}$ & $\begin{array}{l}\text { multi-protein bridging factor } \\
\text { (MBF) 1c (BocMBF1c) }\end{array}$ & $\begin{array}{l}\text { Heat stress: cellular } \\
\text { response to hypoxia, } \\
\text { ethylene-activated } \\
\text { signaling pathway, } \\
\text { positive regulation of } \\
\text { transcription, } \\
\text { DNA-templated } \\
\text { response to abscisic } \\
\text { acid heat, and water } \\
\text { deprivation. }\end{array}$ & $\begin{array}{l}\text { BocMBF1c contains three heat } \\
\text { shock elements (HSEs) and } \\
\text { helix-turn-helix (HTH) domains, } \\
\text { regulating ABRFs, SA, trehalose, } \\
\text { and ET thermal resistance-related } \\
\text { pathways by binding with CTAGA, } \\
\text { including DREB2A. }\end{array}$ & $\begin{array}{c}\text { not presented; } \\
\text { ortholog on } \\
\text { chromosome } 3 \text { of } \\
\text { Arabidopsis thaliana }^{*}\end{array}$ & $-; 0$ & $-; 1^{*}$ & $-; 1^{*}$ & Zou et al. 2019 [18] \\
\hline Soybean (Glycine max) & $\begin{array}{l}\text { Pentatricopeptide-repeat } \\
\text { (PPR) proteins DYW } \\
\text { subgroup genes; GmPPR4 }\end{array}$ & Drought and salt. & $\begin{array}{c}\text { Delayed leaf rolling; higher } \\
\text { content of proline (Pro); and lower } \\
\text { contents of } \mathrm{H} 2 \mathrm{O} 2, \mathrm{O} 2 \text {, and } \\
\text { malondialdehyde (MDA); } \\
\text { increased transcripts of several } \\
\text { drought-inducible genes. }\end{array}$ & $\begin{array}{l}\text { all } 20 \text { chromosomes; } \\
\text { GmPPR4 is on } \\
\text { chromosome } 1 \\
\text { distal end }\end{array}$ & 143 & 36 & 179 & Su et al. 2019 [19] \\
\hline
\end{tabular}


Table 1. Cont.

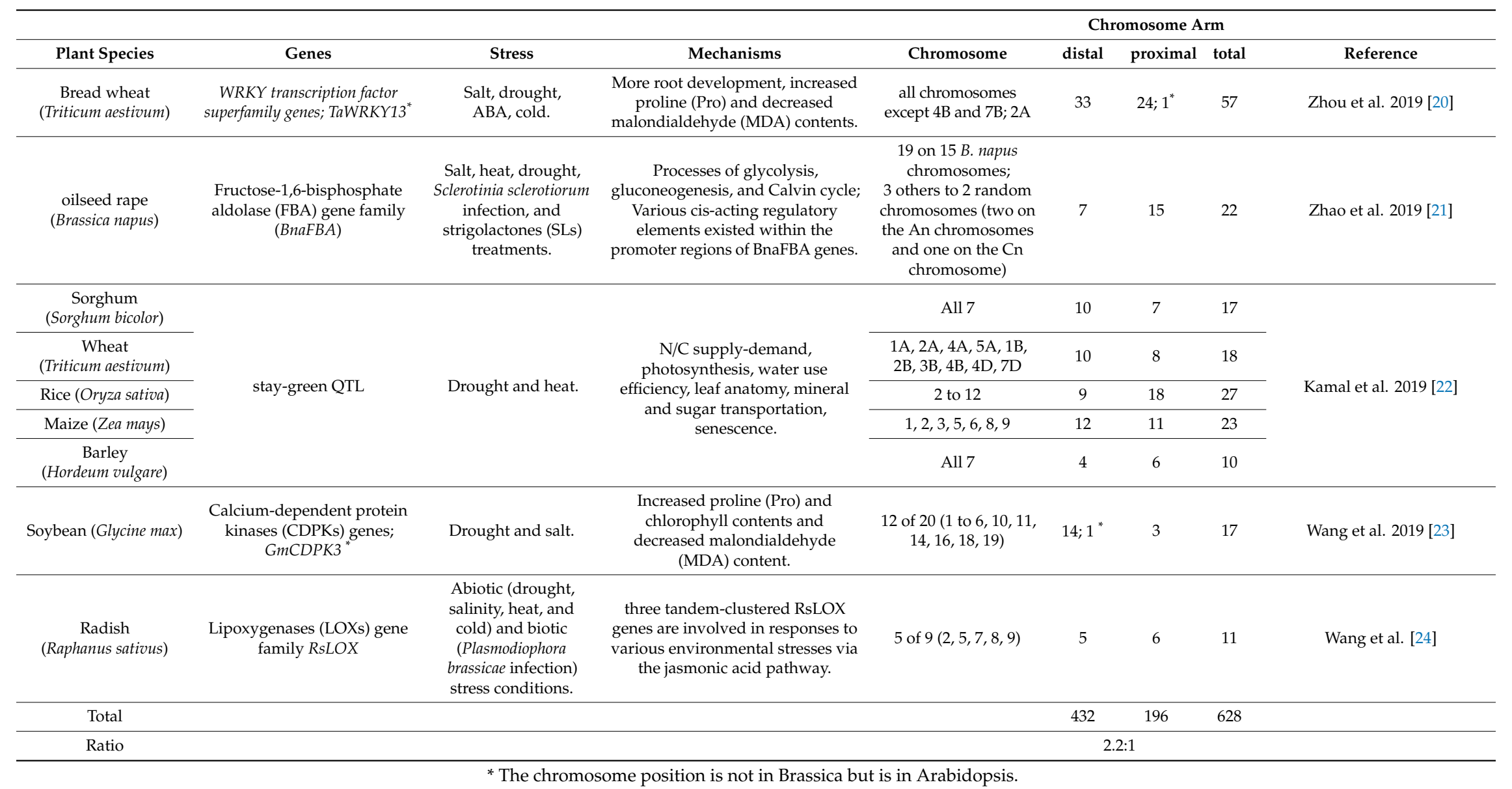


Table 2. Chromosomal distribution of genes controlling resistance to biotic stresses.

\begin{tabular}{|c|c|c|c|c|c|c|c|c|}
\hline \multirow[b]{2}{*}{ Plant Species } & \multirow[b]{2}{*}{ Genes } & \multirow[b]{2}{*}{ Biotic Stress } & \multirow[b]{2}{*}{ Mechanisms } & \multicolumn{5}{|c|}{ Chromosome Arm } \\
\hline & & & & Chromosome & distal & proximal & total & Reference \\
\hline Glycine max & $R p s X$ & $\begin{array}{l}\text { Phytophthora root rot (PRR) } \\
\text { caused by Phytophthora } \\
\text { sojae (Rps). }\end{array}$ & $\begin{array}{l}\text { A 144-bp insertion in the Glyma.03g027200 } \\
\text { sequence resulted in two additional } \\
\text { leucine-rich (LRR) encoding fragments. }\end{array}$ & 3 & 1 & 0 & 1 & Zhong et al. 2019 [25] \\
\hline Oryza sativa & $\begin{array}{l}\text { QTL } q F f R 9 \text { with } 35.15 \% \\
\text { additive effect }\end{array}$ & $\begin{array}{l}\text { Bakanae disease (BD), caused by } \\
\text { the fungal pathogen } \\
\text { Fusarium fujikuroi. }\end{array}$ & $\begin{array}{l}\text { Eight genes in the QTL may be candidate } \\
\text { genes for BD resistance. }\end{array}$ & 9 & 1 & 0 & 1 & Kang et al. 2019 [26] \\
\hline $\begin{array}{l}\text { Triticum } \\
\text { aestivum }\end{array}$ & $18 \mathrm{QTL}$ & $\begin{array}{l}\text { Karnal bunt caused by } \\
\text { Neovossia indica. }\end{array}$ & $\begin{array}{l}\text { QTL are associated with NBS-LRR proteins, } \\
\text { Serine/threonine-protein kinase, Protein } \\
\text { Kinase family protein, Kinase family } \\
\text { protein, Receptor-like kinase, C2H2-like zinc } \\
\text { finger protein, F-box domain containing } \\
\text { protein, Glycosyltransferase and } \\
\text { Transcription factor gene families. }\end{array}$ & $\begin{array}{c}1 \mathrm{D}, 2 \mathrm{~B}, 2 \mathrm{D}, 4 \mathrm{~A}, 4 \mathrm{~B} \\
5 \mathrm{~A}, 5 \mathrm{~B}, 6 \mathrm{~A}, 6 \mathrm{~B}, 7 \mathrm{~B}, 7 \mathrm{D}\end{array}$ & 15 & 3 & 18 & Gupta et al. 2019 [27] \\
\hline Oryza sativa & $\begin{array}{l}\text { Lesion mimic mutant } \\
\text { (LMM) gene } L M M 24\end{array}$ & $\begin{array}{l}\operatorname{lm} 24 \text { exhibited enhanced } \\
\text { resistance to rice blast fungus } \\
\text { Magnaporthe oryzae and } \\
\text { up-regulation of defense } \\
\text { response genes. }\end{array}$ & $\begin{array}{l}\text { Receptor-like cytoplasmic kinase } 109 \\
\text { (OsRLCK109) leads to dark brown lesions in } \\
\text { leaves and growth retardation due to } \\
\text { enhanced ROS accumulation. }\end{array}$ & $\begin{array}{l}\text { LOC_Os03g24930 on } \\
\text { chromosome } 3\end{array}$ & 0 & 1 & 1 & Zhang et al. 2019 [28] \\
\hline $\begin{array}{l}\text { Triticum } \\
\text { aestivum }\end{array}$ & $\begin{array}{l}3 \mathrm{QTL} \text { for stripe rust } \\
\text { resistance }\end{array}$ & $\begin{array}{l}\text { Stripe rust, caused by Puccinia } \\
\text { striformis f. sp. tritici. }\end{array}$ & $\begin{array}{l}\text { QTL on 1B may be Yr29 (an APR gene); the } \\
\text { minor QTL on 2Al may be a new stripe rust } \\
\text { resistance locus; Qyr.saas-7B could be in the } \\
\text { same locus of QYr.nsw-7B from Tiritea. }\end{array}$ & $1 \mathrm{BL}, 2 \mathrm{AL}, 7 \mathrm{BL}$ & 3 & 0 & 3 & Yang et al. 2019 [29] \\
\hline $\begin{array}{l}\text { Triticum } \\
\text { aestivum }\end{array}$ & $\begin{array}{l}124 \text { genomic regions } \\
\text { associated with various } \\
\text { diseases; several genes in } \\
\text { those significant genomic } \\
\text { regions had gene } \\
\text { annotations suggesting } \\
\text { their involvement in } \\
\text { disease resistance. }\end{array}$ & $\begin{array}{l}\text { wheat rusts (leaf; } \text { Puccinia } \\
\text { triticina, stem; P. graminis f.sp. } \\
\text { tritici, and stripe; } \text { P. striformis } \\
\text { f.sp. tritici) and crown rot } \\
\text { (Fusarium spp.); cereal cyst } \\
\text { nematode (Heterodera spp.); and } \\
\text { Hessian fly (Mayetiola destructor). }\end{array}$ & $\begin{array}{l}\text { Five genes were annotated as the } \\
\text { leucine-rich repeat protein family and six } \\
\text { genes were annotated as the F-box family } \\
\text { protein, which were also reported to be } \\
\text { involved in abiotic stress tolerance such as } \\
\text { drought; Calcium-binding protein; } \\
\text { ARM repeat superfamily protein; Elongation } \\
\text { factor } 1 \text { alpha; Peroxidase; WAT1-related } \\
\text { protein/EamA-like transporter family. }\end{array}$ & 21 chromosomes & 97 & 27 & 124 & Bhatta et al. 2019 [30] \\
\hline $\begin{array}{l}\text { Dasypyrum } \\
\text { villosum to } \\
\text { Triticum aestivum }\end{array}$ & Sr52 & $\begin{array}{l}\text { Wheat stem rust caused by } \\
\text { Puccinia graminis f. sp. Tritici. }\end{array}$ & Resistant to stem rust Ug99 races. & $\begin{array}{l}\text { 6V\#3L bin FL } \\
0.92-1.00 \text { to } 6 \mathrm{AL} \text {. }\end{array}$ & 1 & 0 & 1 & Li et al. 2019 [31] \\
\hline
\end{tabular}


Table 2. Cont.

\begin{tabular}{|c|c|c|c|c|c|c|c|c|}
\hline \multirow[b]{2}{*}{ Plant Species } & \multirow[b]{2}{*}{ Genes } & \multirow[b]{2}{*}{ Biotic Stress } & \multirow[b]{2}{*}{ Mechanisms } & \multicolumn{5}{|c|}{ Chromosome Arm } \\
\hline & & & & Chromosome & distal & proximal & total & Reference \\
\hline $\begin{array}{l}\text { Triticum } \\
\text { aestivum }\end{array}$ & $\begin{array}{l}\text { Seven significant additive } \\
\text { QTLs for TS resistance } \\
\text { explaining } 2.98 \text { to } 23.32 \% \\
\text { of the phenotypic } \\
\text { variation; five QTLs } \\
\text { explaining } 5.24 \text { to } 20.87 \% \\
\text { of SNB resistance } \\
\end{array}$ & $\begin{array}{c}\text { Tan Spot (induced by Pyrenophora } \\
\text { tritici-repentis) and Septoria } \\
\text { Nodorum Blotch (caused by } \\
\text { Parastagonospora nodorum). }\end{array}$ & $\begin{array}{l}\text { Quantitative resistance: fungus } \\
\text { P. tritici-repentis isolates produce at least } \\
\text { three host-selective toxins (HSTs), Ptr ToxA, } \\
\text { Ptr ToxB and Ptr ToxC that interact with } \\
\text { products of specific host sensitivity genes } \\
\text { located on chromosome arm 5BL, 2BS., } \\
\text { and 1AS, respectively, to cause disease. }\end{array}$ & $\begin{array}{c}\text { TS }(1 \mathrm{~A}, 1 \mathrm{~B}, 5 \mathrm{~B}, 7 \mathrm{~B} \text { and } \\
7 \mathrm{D}) ; \mathrm{SNB}(1 \mathrm{~A}, 5 \mathrm{~A}, \\
\text { and } 5 \mathrm{~B})\end{array}$ & 7 & 5 & 12 & Singh et al. 2019 [32] \\
\hline $\begin{array}{l}\text { Capsicum } \\
\text { annuum }\end{array}$ & A major QTL $q R R s-10.1$ & $\begin{array}{l}\text { bacterial wilt (BW), caused by } \\
\text { Ralstonia solanacearum. }\end{array}$ & $\begin{array}{l}\text { A cluster of five predicted R genes and three } \\
\text { defense-related genes. }\end{array}$ & chromosome 10 & 0 & 1 & 1 & Du et al. 2019 [33] \\
\hline $\begin{array}{l}\text { Aegilops searsii } \\
\text { to Triticum } \\
\text { aestivum }\end{array}$ & Pm57 & $\begin{array}{l}\text { Powdery mildew caused by } \\
\text { Blumeria graminis f. sp. tritici. }\end{array}$ & $\begin{array}{l}\text { Ten genes that are putative R genes which } \\
\text { includes six coiled-coil nucleotide-binding } \\
\text { site-leucine-rich repeat (CNL), } \\
\text { three nucleotide-binding site-leucine-rich } \\
\text { repeat (NL) and a leucine-rich receptor-like } \\
\text { repeat (RLP) encoding proteins. }\end{array}$ & $\begin{array}{l}2 S^{\mathrm{s}} \# 1 \text {, fraction length } \\
0.72-0.87\end{array}$ & 1 & 0 & 1 & Dong et al. 2020 [34] \\
\hline $\begin{array}{c}\text { Vitis } \\
\text { quinquangularis }\end{array}$ & $\begin{array}{l}\text { Transcription Factor } \\
\text { VqMYB14 }\end{array}$ & $\begin{array}{l}\text { bacterial flagellin peptide flg22 } \\
\text { and harpins (glycine-rich and } \\
\text { heat-stable proteins that are } \\
\text { secreted through type III } \\
\text { secretion system in } \\
\text { gram-negative } \\
\text { plant-pathogenic bacteria). }\end{array}$ & $\begin{array}{l}\text { The promoter of } V q M Y B 14 \text { is induced by the } \\
\text { elicitors flg22 to confer basal immunity (also } \\
\text { called pathogen-associated molecular } \\
\text { pattern (PAMP)-triggered immunity, PTI) } \\
\text { and triggered by harpin to confer } \\
\text { effector-triggered immunity (ETI). } \\
\text { Overexpression of } V q M Y B 14 \text { enhance the } \\
\text { main stilbene contents and expression of } \\
\text { stilbene biosynthesis genes. }\end{array}$ & chromosome 7 & 0 & 1 & 1 & Luo et al. 2020 [3] \\
\hline Total & & & & & 126 & 38 & 164 & \\
\hline Ratio & & & & & & & & \\
\hline
\end{tabular}




\section{Chromosomal Distribution Patterns of Genes for Abiotic-Stress Tolerance vs. Biotic-Stress Resistance}

Studying abiotic-stress tolerance, the authors of these 21 articles in this Special Issue covered Hordeum vulgare, Gossypium hirsutum, Pyrus pyrifolia, Oryza sativa, Glycine max, Fragaria vesca, Cucumis sativus, Dianthus caryophyllus, Brassica oleracea, B. napus, Sorghum bicolor, Triticum aestivum, Zea mays, Raphanus sativus, and the model plant Arabidopsis thaliana (Table 1). The abiotic stresses studied include cold, heat, drought, salt, iron deficiency, nitrogen deficiency, UV irradiation, DNA damage, reducing agent, phytohormones (GA, SA, JA, ABA, ethylene, 2,4-D, and NAA), and heavy metals (cadmium, nickel and cobalt). Two [6,7] of the 21 articles did not present information on the chromosomal locations of genes for abiotic-stress tolerance, and one [18] did not map the BocMBF1c gene to the target species B. oleracea but did locate the orthologous gene identified in A. thaliana to the proximal section of chromosome 3.

Many transcription factor gene families (TFs) were studied in the majority of these 21 articles $[6,8,9,11,13-20,23,24]$. Various putative stress-related and hormone-responsive cis-acting regulatory elements were identified in the promotor of these TFs. "The cis-regulatory sequences are linear nucleotide fragments of non-coding DNA with the main role of regulating gene expression and in turn, controls the development and physiology of an organism" [35]. Therefore, variations among members of TFs observed in those studies might account for the varying regulation of gene expression in different organs and tissues or at different developmental stages to respond to different stresses.

Among the 11 articles in the Special Issue on plant genes conferring resistance to biotic stresses [3,25-34], seven articles reported results from single resistant genes (or QTL) for crops and plant species, including soybean, rice, wheat, Dasypyrum villosum, Aegilops searsii, Capsicum annuum, and Vitis quinquangularis. The other four articles [27,29,30,32] analyzed multiple QTLs or genomic regions for one or more diseases.

For genes controlling tolerance to abiotic stresses, an averaged 2.2 to 1 ratio of distal to proximal chromosomal distribution was obtained from the 21 articles (Table 1). In comparison, the 11 articles on genes conferring resistance to biotic stresses resulted in a 3.3 to 1 ratio (Table 2). Therefore, $77 \%$ of genes conferring resistance to biotic stresses were located in the distal section of chromosomes, while $69 \%$ of those for abiotic-stress tolerance were distally located. This slightly higher number of genes in the distal section of chromosomes is advantageous for plant adaptation, because genetic variability generated from the high recombination rate in distal recombination hotspots enables plants to deal with environmental changes and new virulent pests.

Conflicts of Interest: The author declares no conflicts of interest.

\section{References}

1. Assmann, S.M. Natural variation in abiotic stress and climate change responses in Arabidopsis: Implications for twenty-first-century agriculture. Int. J. Plant Sci. 2013, 174, 3-26. [CrossRef]

2. Atkinson, N.J.; Urwin, P.E. The interaction of plant biotic and abiotic stresses: From genes to the field. J. Exp. Bot. 2012, 63, 3523-3543. [CrossRef] [PubMed]

3. Luo, Y.Y.; Wang, Q.Y.; Bai, R.; Li, R.X.; Chen, L.; Xu, Y.F.; Zhang, M.; Duan, D. The effect of transcription factor MYB14 on defense mechanisms in Vitis quinquangularis-Pingyi. Int. J. Mol. Sci. 2020, 21, 706. [CrossRef] [PubMed]

4. Wang, X.K.; Gong, X.; Cao, F.B.; Wang, Y.Z.; Zhang, G.P.; Wu, F.B. HvPAA1 encodes a P-Type ATPase, a novel gene for cadmium accumulation and tolerance in barley (Hordeum vulgare L.). Int. J. Mol. Sci. 2019, 20, 1732. [CrossRef] [PubMed]

5. Xu, Y.C.; Magwanga, R.O.; Cai, X.Y.; Zhou, Z.L.; Wang, X.X.; Wang, Y.H.; Zhang, Z.M.; Jin, D.S.; Guo, X.L.; Wei, Y.Y.; et al. Deep transcriptome analysis reveals reactive oxygen species (ROS) network evolution, response to abiotic stress, and regulation of fiber development in cotton. Int. J. Mol. Sci. 2019, 20, 1863. [CrossRef]

6. Ahmad, M.; Li, J.Z.; Yang, Q.S.; Jamil, W.; Teng, Y.W.; Bai, S.L. Phylogenetic, molecular, and functional characterization of PpyCBF proteins in Asian pears (Pyrus pyrifolia). Int. J. Mol. Sci. 2019, 20, 2074. [CrossRef] [PubMed] 
7. Zhang, X.X.; Zhang, D.; Sun, W.; Wang, T.Z. The adaptive mechanism of plants to iron deficiency via iron uptake, transport, and homeostasis. Int. J. Mol. Sci. 2019, 20, 2424. [CrossRef]

8. Yong, Y.B.; Zhang, Y.; Lyu, Y.M. A stress-responsive NAC transcription factor from tiger lily (LlNAC2) interacts with LIDREB1 and LIZHFD4 and enhances various abiotic stress tolerance in Arabidopsis. Int. J. Mol. Sci. 2019, 20, 3225. [CrossRef]

9. Yong, Y.B.; Zhang, Y.; Lyu, Y.M. A MYB-related transcription factor from Lilium lancifolium L. (LIMYB3) is involved in anthocyanin biosynthesis pathway and enhances multiple abiotic stress tolerance in Arabidopsis thaliana. Int. J. Mol. Sci. 2019, 20, 3195. [CrossRef]

10. Yoon, M.Y.; Kim, M.Y.; Ha, J.; Lee, T.; Kim, K.D.; Lee, S.H. QTL analysis of resistance to high-intensity UV-B irradiation in soybean (Glycine max [L.] Merr.). Int. J. Mol. Sci. 2019, 20, 3287. [CrossRef]

11. Chen, H.; Li, H.H.; Lu, X.Q.; Chen, L.Z.; Liu, J.; Wu, H. Identification and expression analysis of GRAS transcription factors to elucidate candidate genes related to stolons, fruit ripening and abiotic stresses in woodland strawberry (Fragaria vesca). Int. J. Mol. Sci. 2019, 20, 4593. [CrossRef] [PubMed]

12. Katiyar, A.; Mudgil, Y. Arabidopsis NDL-AGB1 modules play role in abiotic stress and hormonal responses along with their specific functions. Int. J. Mol. Sci. 2019, 20, 4736. [CrossRef] [PubMed]

13. Noman, M.; Jameel, A.; Qiang, W.D.; Ahmad, N.; Liu, W.C.; Wang, F.W.; Li, H.Y. Overexpression of GmCAMTA12 enhanced drought tolerance in Arabidopsis and soybean. Int. J. Mol. Sci. 2019, 20, 4849. [CrossRef] [PubMed]

14. Magwanga, R.O.; Kirungu, J.N.; Lu, P.; Cai, X.Y.; Zhou, Z.L.; Xu, Y.C.; Hou, Y.Q.; Agong, S.G.; Wang, K.B.; $\mathrm{Liu}, \mathrm{F}$. Map-based functional analysis of the GhNLP genes reveals their roles in enhancing tolerance to N-deficiency in cotton. Int. J. Mol. Sci. 2019, 20, 4953. [CrossRef] [PubMed]

15. Li, S.Z.; Miao, L.; Huang, B.; Gao, L.H.; He, C.X.; Yan, Y.; Wang, J.; Yu, X.C.; Li, Y.S. Genome-wide identification and characterization of cucumber BPC transcription factors and their responses to abiotic stresses and exogenous phytohormones. Int. J. Mol. Sci. 2019, 20, 5048. [CrossRef] [PubMed]

16. Li, W.; Wan, X.L.; Yu, J.Y.; Wang, K.L.; Zhang, J. Genome-wide identification, classification, and expression analysis of the Hsf gene family in carnation (Dianthus caryophyllus). Int. J. Mol. Sci. 2019, 20, 5233. [CrossRef] [PubMed]

17. Imran, M.; Shafiq, S.; Farooq, M.A.; Naeem, M.K.; Widemann, E.; Bakhsh, A.; Jensen, K.B.; Wang, R.R.-C. Comparative genome-wide analysis and expression profiling of histone acetyltransferase (HAT) gene family in response to hormonal applications, metal and abiotic stresses in cotton. Int. J. Mol. Sci. 2019, 20, 5311. [CrossRef]

18. Zou, L.F.; Yu, B.W.; Ma, X.L.; Cao, B.H.; Chen, G.J.; Chen, C.M.; Lei, J.J. Cloning and expression analysis of the BocMBF1c gene involved in heat tolerance in Chinese kale. Int. J. Mol. Sci. 2019, 20, 5637. [CrossRef]

19. Su, H.G.; Li, B.; Song, X.Y.; Ma, J.; Chen, J.; Zhou, Y.B.; Chen, M.; Min, D.H.; Xu, Z.S.; Ma, Y.Z. Genome-wide analysis of the DYW subgroup PPR gene family and identification of GmPPR4 responses to drought stress. Int. J. Mol. Sci. 2019, 20, 5667. [CrossRef]

20. Zhou, S.; Zheng, W.J.; Liu, B.H.; Zheng, J.C.; Dong, F.S.; Liu, Z.F.; Wen, Z.Y.; Yang, F.; Wang, H.B.; Xu, Z.S.; et al. Characterizing the role of TaWRKY13 in salt tolerance. Int. J. Mol. Sci. 2019, 20, 5712. [CrossRef]

21. Zhao, W.; Liu, H.F.; Zhang, L.; Hu, Z.Y.; Liu, J.; Hua, W.; Xu, S.M.; Liu, J. Genome-wide identification and characterization of FBA gene family in polyploid crop Brassica napus. Int. J. Mol. Sci. 2019, $20,5749$. [CrossRef] [PubMed]

22. Kamal, N.M.; Gorafi, Y.S.A.; Abdelrahman, M.; Abdellatef, E.; Tsujimoto, H. Stay-green trait: A prospective approach for yield potential, and drought and heats stress adaptation in globally important cereals. Int. J. Mol. Sci. 2019, 20, 5837. [CrossRef] [PubMed]

23. Wang, D.; Liu, Y.X.; Yu, Q.; Zhao, S.P.; Zhao, J.Y.; Ru, J.N.; Cao, X.Y.; Fang, Z.W.; Chen, J.; Zhou, Y.B.; et al. Functional analysis of the soybean GmCDPK3 gene responding to drought and salt stresses. Int. J. Mol. Sci. 2019, 20, 5909. [CrossRef] [PubMed]

24. Wang, J.L.; Hu, T.H.; Wang, W.L.; Hu, H.J.; Wei, Q.Z.; Wei, X.C.; Bao, C.L. Bioinformatics analysis of the lipoxygenase gene family in radish (Raphanus sativus) and functional characterization in response to abiotic and biotic stresses. Int. J. Mol. Sci. 2019, 20, 6095. [CrossRef]

25. Zhong, C.; Li, Y.P.; Sun, S.L.; Duan, C.X.; Zhu, Z.D. Genetic mapping and molecular characterization of a broad-spectrum Phytophthora sojae resistance gene in Chinese soybean. Int. J. Mol. Sci. 2019, 20, 1809. [CrossRef]

26. Kang, D.Y.; Cheon, K.S.; Oh, J.; Oh, H.; Kim, S.L.; Kim, N.; Lee, E.; Choi, I.; Baek, J.; Kim, K.H.; et al. Rice genome resequencing reveals a major quantitative trait locus for resistance to Bakanae disease caused by Fusarium fujikuroi. Int. J. Mol. Sci. 2019, 20, 2598. [CrossRef] 
27. Gupta, V.; He, X.Y.; Kumar, N.; Fuentes-Davila, G.; Sharma, R.K.; Dreisigacker, S.; Juliana, P.; Ataei, N.; Singh, P.K. Genome wide association study of Karnal bunt resistance in a wheat germplasm collection from Afghanistan. Int. J. Mol. Sci. 2019, 20, 3124. [CrossRef]

28. Zhang, Y.; Liu, Q.; Zhang, Y.X.; Chen, Y.Y.; Yu, N.; Cao, Y.R.; Zhan, X.D.; Cheng, S.H.; Cao, L.Y. LMM24 encodes receptor-like cytoplasmic kinase 109, which regulates cell death and defense responses in rice. Int. J. Mol. Sci. 2019, 20, 3243. [CrossRef]

29. Yang, M.Y.; Li, G.R.; Wan, H.S.; Li, L.P.; Li, J.; Yang, W.Y.; Pu, Z.J.; Yang, Z.J.; Yang, E.N. Identification of QTLs for stripe rust resistance in a recombinant inbred line population. Int. J. Mol. Sci. 2019, 20, 3410. [CrossRef]

30. Bhatta, M.; Morgounov, A.; Belamkar, V.; Wegulo, S.N.; Dababat, A.A.; Erginbas-Orakci, G.; El Bouhssini, M.; Gautam, P.; Poland, J.; Akci, N.; et al. Genome-wide association study for multiple biotic stress resistance in synthetic hexaploid wheat. Int. J. Mol. Sci. 2019, 20, 3667. [CrossRef]

31. Li, H.H.; Dong, Z.J.; Ma, C.; Tian, X.B.; Qi, Z.J.; Wu, N.; Friebe, B.; Xiang, Z.G.; Xia, Q.; Liu, W.X.; et al. Physical mapping of stem rust resistance gene Sr52 from Dasypyrum villosum based on ph1b-Induced homoeologous recombination. Int. J. Mol. Sci. 2019, 20, 4887. [CrossRef] [PubMed]

32. Singh, P.K.; Singh, S.; Deng, Z.Y.; He, X.Y.; Kehel, Z.; Singh, R.P. Characterization of QTLs for seedling resistance to Tan Spot and Septoria Nodorum Blotch in the PBW343/Kenya Nyangumi wheat recombinant inbred lines population. Int. J. Mol. Sci. 2019, 20, 5432. [CrossRef] [PubMed]

33. Du, H.S.; Wen, C.L.; Zhang, X.F.; Xu, X.L.; Yang, J.J.; Chen, B.; Geng, S.S. Identification of a major QTL (qRRs-10.1) that confers resistance to Ralstonia solanacearum in pepper (Capsicum annuum) using SLAF-BSA and QTL mapping. Int. J. Mol. Sci. 2019, 20, 5887. [CrossRef] [PubMed]

34. Dong, Z.J.; Tian, X.B.; Ma, C.; Xia, Q.; Wang, B.L.; Chen, Q.F.; Sehgal, S.K.; Friebe, B.; Li, H.H.; Liu, W.X. Physical mapping of Pm57, a powdery mildew resistance gene derived from Aegilops searsii. Int. J. Mol. Sci. 2020, 21, 322. [CrossRef]

35. Wittkopp, P.J.; Kalay, G. Cis-regulatory elements: Molecular mechanisms and evolutionary processes underlying divergence. Nat. Rev. Genet. 2011, 13, 59-69. [CrossRef]

(C) 2020 by the author. Licensee MDPI, Basel, Switzerland. This article is an open access article distributed under the terms and conditions of the Creative Commons Attribution (CC BY) license (http://creativecommons.org/licenses/by/4.0/). 